\title{
ASSESSMENT OF OSTEOPOROSIS AND OCCURRENCE OF VERTEBRAL FRACTURES IN POSTMENOPAUSAL PATIENTS WITH RHEUMATOID ARTHRITIS TREATED WITH SMALL DOSES OF GLUCOCORTICOIDS
}

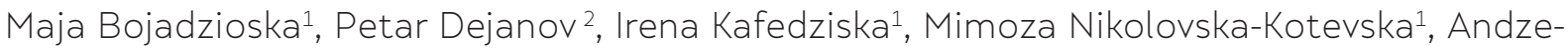

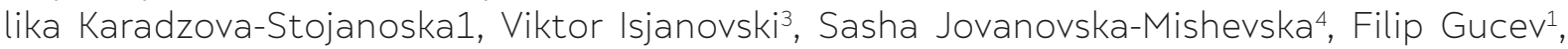
Igor Isjanovski ${ }^{5}$, Elena Curakova Ristovska ${ }^{6}$

University Clinic for Rheumatology; Faculty of Medicine, Ss. Cyril and Methodius University, Skopje, Republic of North Macedonia

University Clinic for Nephrology; Faculty of Medicine, Ss. Cyril and Methodius University, Skopje, Republic of North Macedonia

Psychiatric Hospital "Skopje"; Faculty of Medicine, Ss. Cyril and Methodius University, Skopje, Republic of North Macedonia

University Clinic for Endocrinology; Faculty of Medicine, Ss. Cyril and Methodius University, Skopje, Republic of North Macedonia

University Clinic for Ophthalmology; Faculty of Medicine, Ss. Cyril and Methodius University, Skopje, Republic of North Macedonia

University Clinic for Gastroenterohepatology; Faculty of Medicine, Ss. Cyril and Methodius University, Skopje, Republic of North Macedonia

\begin{abstract}
Citation: Bojadzioska M, Dejanov P, Kafedziska I, Nikolovska-Kotevska M, Karadzova-Stojanoska A, Isjanovski V, Jovanovska-Mishevska S, Gucev F Isjanovski I, Curakova Ristovska E. Assessment of osteoporosis and occurrence of vertebral fractures in postmenopausal patients with rheumatoid arthritis treated with small doses of glucocorticoids. Arch Pub Health 2020; 12 (3).

doi.org/10.3889/aph.2020.5608

Key words: vertebral fractures, rheumatoid arthritis, glucocorticoids, osteoporosis

*Correspondence: Maja Bojadzioska. University Clinic for Rheumatology, Skopie, Republic of North Macedonia, E-mail: majajurukovska@yahoo.com Received: 26-Mav-2020; Revised: 30-Jun-2020; Accepted: 5-Jul-2020; Published: 15-Dec-2020

Copyright: 2020. Maja Bojadzioska. This is an open-access article distributed under the terms of the Creative Commons Attribution License, which permits unrestricted use, distribution, and reproduction in any medium, provided the original author(s) and source are credited.

Competing Interests: The author have declared that no competing interests
\end{abstract}

Клнички истражувања

\section{Abstract}

Osteoporosis (OP) is a serious extracorporeal manifestation that occurs in patients with rheumatoid arthritis (RA). One of the risk factors is long-term use of glucocorticoids (GC). Osteoporosis together with the increased risk of vertebral (VF) and non-vertebral fractures (non-VF) in particular has a negative impact on quality of life in patients with rheumatoid arthritis. The aim of the study was to detect the occurrence of OP and VF in postmenopausal patients with RA and their association with long-term use of small doses of glucocorticoids. Material and methods: A total of 46 patients were analyzed. All respondents underwent imaging for osteoporosis evaluation with a DXA scanner (Lunar iDXA, GE) and VF with incorporated Vertebral Fracture Assessment (VFA). Results: The values of bone mineral densities (BMD) were significantly smaller in the group that received glucocorticoids. According to VFA, 37,0\% of patients were registered to have a fracture of middle degree, a mild fracture was registered in $19.6 \%$ of patients, and severe fractures were registered in 3 patients (6.5\%). Conclusion: In postmenopausal patients with RA receiving GC therapy, a more common occurrence of osteoporosis and vertebral fractures was reported compared with the remaining group of RA patients. All patients with RA in menopause need to be screened for timely detection and treatment of osteoporosis and prevention of its complications.

\section{ПРОЦЕНКА НА ОСТЕОПОРОЗАТА И ПОЈАВА НА ВЕРТЕБРАЛНИ ФРАКТУРИ КАЈ ПОСТМЕНОПАУЗНИ ПАЦИЕНТКИ СО РЕВМАТОИДЕН АРТРИТИС ТРЕТИРАНИ СО МАЛИ ДОЗИ НА ГЛИКОКОРТИКОИДИ}

\footnotetext{
Маја Бојаџиоска르. Петар Дејанов², Ирена Кафеџискаㄱ, Мимоза Николовска-Котевска ${ }^{1}$, Анжелика Караџова-Стојаноска ${ }^{1}$, Виктор Исјановски구, Саша Јовановска- Мишевска4 Филип Гучев ${ }^{1}$, Игор Исјановски

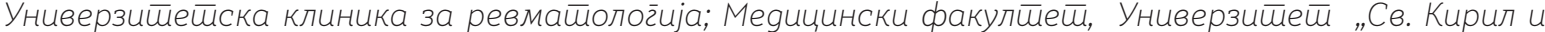
Меш̄оguj", Скойје, Рейублика Северна Макеgонија

Универзишешеиска клиника за нефролог̈ија; Меgицински факулиееш, Универзишеей „Св. Кирил и Меш̄оguj”, Скойје, Рейублика Северна Макеgонија

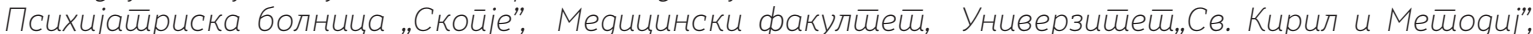
Скойје, Реӣублика Северна Макеgонија

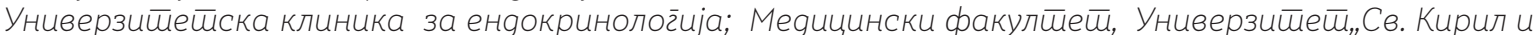
Мейоguj", Скойје, Рейублика Северна Макеgонија

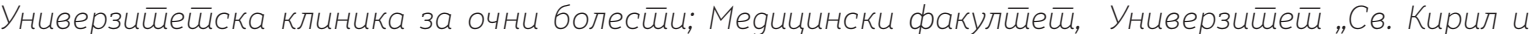
Мет̄оguj", Скойје, Рейублика Северна Макеgонија

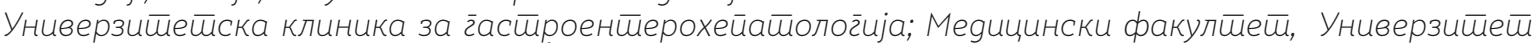
„Св. Кирил и Меш̄оguj”, Скойје, Реӣублика Северна Макеgонија
} 


\section{Извадок}

Цитирање: Бојаџиоска М, Дејанов П, Ка феџиска И, Николовска-Котевска М, караџова-Стојаноска А, Исјановски В, Јовановска- Мишевска С, Тучев Ф, Исјановски И Цуракова-Ристовска Е. Проценка на остеопо розата и појава на вертебрални фрактури ка постменопаузни пациентки со ревматоиден артритис третирани со мали дози на гликокортикоиди. Арх J Здравје 2020;12(3) doi.org/10.3889/aph.2020.5608

Клучни зборови: вертебрални фрактури ревматоиден артрит, гликокортикоиди, остеопороза

*Кореспонденција: Маја Бојаџиоска, Универ зитетска клиника за ревматологија, Скопје, Република Северна Македонија. E-mail: majajurukovska@yahoo.com

Примено: 26-мај-2020; Ревидирано: 30-јун-2020 Прифатено: 5-јул-2020; Објавено: 15-дек-2020

Печатарски права: 2020 Маја Бојаџиоска. Оваа статија е со отворен пристап дистрибуирана под условите на нелокализирана лиценца, која овозможува неограничена употреба, дистрибуција и репродукција на било кој ме диум, Доколку се цитираат оригиналниот(ите
автор(и) и изворот.

Конкурентски интереси: Авторот изјавува дека нема конкурентски интереси.
Остеопорозата (OP) е сериозна вонзглобна манифестација која се јавува кај пацинетки со ревматоиден артритис (RA). Еден од ризик-факторите претставува долготрајната примена на гликокортикоиди (GC). Остеопорозата заедно со зголемениот ризик од вертебрални (VF) и невертебрални фрактури (non-VF) има негативно влијание врз квалитетот на живот кај пациентките со ревматоиден артритис. Целта на трудот беше да се детектира појавата на OP и VF кај постменопаузни пациентки со RA и нивната поврзаност со долготрајната примена на мали дози гликокортикоиди. Материјал и методи: Беа анализирани 46 пациентки. Кај сите беше направено снимање за евалуација на остеопороза со апарат за двојно-енергетска х-зрачна апсорпциометрија - DXA скен, “Lunar iDXA”, производство на GE, со вграден софтвер за проценка на VF, VFA (Vertebral Fracture Assessment). Резултати: Вредностите на коскениот минерален дензитет (BMD) беа сигнификантно помали во групата која примала гликокортикоиди. Според VFA, кај 37,0\% од пациентките беше регистрирана фрактура од среден степен, кај 19,6\% лесна фрактура, а тешка фрактура беше регистрирана кај три пациентки (6,5\%). Заклучок: Кај постменопаузните пациентки со RA кои примаа терапија со GC беше регистрирана почеста појава на OР како и VF споредено со останатата група пациентки со ревматоиден артритис. Кај сите пациенки со RA во менопауза, потребно е навремено детектирање и третман на остеопорозата и превенирање на нејзините компликации. 


\section{Вовед}

Ревматоидниот артритис (RA) е хронична, системска, автоимуна болест со прогресивен карактер која ги зафаќа првенствено зглобовите, доведувајќи до нивно оштетување и функционален губиток, но може да бидат зафатени и други органи и системи, придонесувајќи притоа до намалување на квалитетот на живеење ${ }^{1}$.

Остеопорозата (OP) е сериозна вонзглобна манифестација која се јавува кај пациентки со RA и корелира со тежината и активноста на болеста. Додатни ризик-фактори претставуваат долготрајната примена на гликокортикоидите (GC) како и смалената физичка активност на пациентите заради дисабилитетот ${ }^{2}$. Голем број од пациентките со RA се на терапија со гликокортикоиди. Околу 30-50\% од пациентките co RA кои земаат GC подолго од три месеци имаат зголемен ризик од појава на фрактури. Најмалата доза на GC која го зголемува ризикот од фрактура е 5мг/дневно-преднизолонски еквивалент ${ }^{3}$.

Присуството на една вертебрална фрактура (VF) го зголемува релативниот ризик од идни VFs како и појава на невертебрални фрактури (non-VF). Овие компликации на ОР може да се јават и независно од коскената минерална густина - BMD (bone mineral density) ${ }^{4}$. Остеопорозата, заедно со зголемениот ризик од VF и non-VF, има негативно влијание врз квалитетот на живот кај пациентките со RA и претствува сериозен здравствен и социоекономски проблем ${ }^{5}$.

Етиологијата на коскениот губиток може да биде мултифакторска. Активноста на болеста кај RA корелира со коскениот губиток и се карактеризира со ослободување на проинфламаторни цитокини, како што се интерлеукин 6 (IL-6) и тумор- некротизирачки фактор алфа (TNF-alfa) и други, со потекло од воспалителната синовија6. Дополнителни фактори кои придонесуваат за коскен губиток кај RA се намалената физичка активност и употребата на лекови како што се гликокортикоидите ${ }^{3,4}$.

Целта на трудот беше да се детектира појавата на OP и VF кај постменопаузални пациентки со RA и нивната поврзаност со долготрајната примена на мали дози гликокортикоиди.

\section{Материјал и методи}

Се работи за аналитичка студија на пресек, изработена во период од една година - март 2019 до март 2020 година, во која беа вклучени 46 пациентки со етаблирана дијагноза за RA според ревидираните ACR критериуми од 1987 година7 Испитаниците беа лекувани амбулантски и хоспитално на Универзитетската клиника за ревматологија во Скопје. Тоа беа постменопаузни жени на возраст од 50 до 80 години, со траење на менопаузата од $\geq 2$ години. Во студијата беа вклучени пациентки кои претходно не биле лекувани со бисфосфонатна терапија. Кај сите испитаници со RA беше дозволено лекување со различни НСАИЛ и/или антиревматици кои го модифицираат текот на болеста (DMARDs) како и со гликокортикоидна терапија. Испитаниците кои припаѓаа на функционалната класа 4 според Steinbrocher, не беа вклучени во студијата.

Кај сите 46 испитаници беше земена анамнеза со прегледан статус по системи од страна на ревматолог. Коскената минерална густина беше одредувана со апарат за двојно-енергетска х-зрачна апсорпцио- 
метрија - DXA скенер, "Lunar iDXA", производство на GE, со проценка на VF со методот VFA (Vertebral Fracture Assessment). Коскениот губиток беше изразен во Т-score кој го дефинира отстапувањето на коскената густина во стандардни девијации (SD), споредено со истата кај млади, здрави жени. DXA апаратот се наоѓa на Ј3У Универзитетска клиника за ревматологија, Скопје. Вертебралните фрактури се одредуваат со помош на VFA која е вградена во софтверот на DXA апаратот. Проценката на вертебралните фрактури (VFA) е метод за снимање на тораколумбарниот ,рбет со помош на коскениот дензитометар и претставува брза и едноставна процедуpa, поврзана со мала изложеност на радијација и има добра способност за откривање на вертебралните фрактури ${ }^{4}$.

Дозата на зрачењето за пациентот е многу помала за разлика од стандардното рендгенско снимање (3 $\mu S V$ од T4-Л4 кај VFA, а $600 \mu S V$ за стандардна рендгенска снимка на лумбалниот 'рбет). По снимањето, следи мануелно или автоматско подесување на VFA сликата, а резултатот се изразува во проценти, односно се користи семиквантитативен метод според Генант ${ }^{8}$. Кога се користи семиквантитативна техника на проценување, се определуваат три степена на коскен губиток. Кај степен 1 - мал губиток на коскена маса, станува збор за губење на висината на прешленското тело од 20 до 25\%. Среден губиток на коскена маса, степен 2, се карактеризира со намалување на висината на прешленското тело за 25 до 40\%. Сериозен губиток на коскената маса, степен 3, се јавува кога висината на прешленското тело е намалена за повеќе од 40\%. Секое губење на висината на прешленското тело поголемо од 20\% т.е. 4 мм од стан- дардната височина се смета за вертебрална фрактура9.

Во истражувањето беа почитувани етичките начела на Хелсиншката декларација на Светската медицинска асоцијација, Belmont извештајот и UNESCO-вата Универзална декларација за биоетика и човекови права. Исто така, се почитуваа и критериумите за Основна добра клиничка пракса, Законот за здравствена заштита и Законот за права на пациенти на Република Северна Македонија.

Критериуми за невклучување во студијата беа: акутни и хронични инфекции кои коинцидираат со RA, хепатални, бубрежни, белодробни или хематолошки заболувања, шеќерна болест, болести на тироидната и паратироидната жлезда, болести на надбубрежната жлезда, сите видови на хормонска заместувачка терапија кај постменопаузните жени, терапија со бисфосфонати, психијатриски и невролошки заболувања.

Статистичката анализа беше изработена во статистичкиот програм: STATISTICA 10.0. Атрибутивните статистички серии беа анализирани со одредување на коефициент на односи, пропорции, стапки и со утврдување на статистичката значајност помеѓу откриените разлики - Fisher Exact 2 tailed test. Нумеричките серии беа анализирани со мерки на централна тенденција и со мерки на дисперзија на податоците. Кај нумеричките серии кај кои не постоеше отстапување од нормалната дистрибуција, сигнификантноста на разликата се тестираше со t-тест. За CI (confindence интервал 95\% CI) беше дефинирана статистичката значајност за ниво на грешка помало од 0,05 (p). Резултатите се прикажани табеларно. 


\section{Резултати}

Во студијата беа вклучени 46 пациентки со просечна возраст од $62 \pm 7,9$ г., во опсег од 52 до 80-годишна возраст; со просечна тежина од 70,4 $\pm 14,0$ кг, $157 \pm 0,07$ см; и индекс на телесна маса (BMI) од 28,6 , во опсег од 18,4 до 39,6 (од нормална телесна тежина до гојазност). Кај 43 пациентки траењето на болеста беше од 5 до 15 години, а кај 3 пациентки подолго од 15 години. Остеопороза беше регистрирана кај 6,6\% од пациентките, а остеопенија кај 63,6\%. Беше регистрирана сигнификантна поврзаност помеѓ $\mathrm{BMD}$ и земањето гликокортикоиди за $\mathrm{p}<0,05$ (0,025533).

Просечната вредност на вкупниот T-score на L1-L4 изнесуваше -1,3 $\pm 1,0$ SD, во опсег од -3,8 до 0,2 SD. Просечната вредност кај пациентките кои земаа GC изнесуваше -1,6 SD, а кај пациентките без GC e -0,5SD. Разликата беше статистички сигнификантна за $\mathrm{p}<0,05$ (0,171972).

Вредностите на вкупниот T-score на левиот колк кај пациентките со и без GC терапија се движеше од -2,3 SD во групата која примала мали дози на GK до 0,5 SD во групата со PA која не примала гликокортикоиди. Разликата беше статистички сигнификантна за $\mathrm{p}<0,05$ $(0,000001)$.

При изработка на VFA, кај 37,0\% од пациентките беа забележани VF од среден степен (степен 2). Лесни фрактури (степен 1) се регистрираа кај 19,6\%, а кај три пациентки (6,5\%) беа регистрирани тешки фрактури од степен 3. Постоеше сигнификантна поврзаност помеѓу појавата на VFA и земањето гликокортикоиди за $\mathrm{p}<0,05$ (0,040160).

\begin{tabular}{|c|c|c|c|c|c|c|c|c|}
\hline \multicolumn{6}{|c|}{ Вкупен број пациенти } & \multicolumn{2}{|c|}{ Гликокортикоиди } & \multirow{2}{*}{$\frac{\text { t-тест }}{\mathrm{P}}$} \\
\hline & $\mathrm{N}$ & Просек & Минимум & Максимум & Стд.Дев. & $\begin{array}{c}\text { Просек/ } \\
\text { со }\end{array}$ & $\begin{array}{c}\text { Просек/ } \\
\text { без }\end{array}$ & \\
\hline Возраст & 46 & 62,0 & 52,0 & 80,0 & 7,93865 & 62,3 & 58,0 & 0,372623 \\
\hline TT / kg & 46 & 70,4 & 43,0 & 98,0 & 13,96898 & 69,4 & 84,0 & 0,080779 \\
\hline Висина /m & 46 & 1,56 & 1,44 & 1,66 & 0,06621 & 1,6 & 1,7 & 0,028289 \\
\hline BMI & 46 & 28,6 & 18,4 & 39,6 & 5,49221 & 28,4 & 30,9 & 0,463059 \\
\hline $\begin{array}{c}\text { BMD (g/ } \\
\text { cm2-L1-L4 }\end{array}$ & 46 & 1,03 & 0,729 & 1,209 & 0,119380 & 1,0 & 1,1 & 0,170528 \\
\hline $\begin{array}{c}\text { Вкупен } \\
\text { T-score L1- } \\
\text { L4 / SD }\end{array}$ & 46 & $-1,3$ & $-3,8$ & 0,2 & 1,003077 & $-1,3$ & $-0,5$ & 0,171972 \\
\hline $\begin{array}{c}\text { Вкупен } \\
\text { T-score лев } \\
\text { колк /SD }\end{array}$ & 46 & $-1,5$ & $-2,3$ & 0,5 & 0,800764 & $-1,6$ & 0,5 & 0,000001 \\
\hline \multicolumn{6}{|c|}{ Вкупен број пациенти } & \multicolumn{2}{|c|}{ Гликокортикоиди } & $\mathrm{P}$ \\
\hline \multicolumn{4}{|c|}{ Времетраење на болест } & Број & $\%$ & Број/со & Броі/без & 0,259783 \\
\hline \multicolumn{4}{|l|}{$5-10 \Gamma$} & 18 & 39,1 & 18 & 0 & \\
\hline \multicolumn{4}{|l|}{$10-15 г$} & 25 & 54,4 & 22 & 3 & \\
\hline \multicolumn{4}{|l|}{$>15 \Gamma$} & 3 & 6,5 & 3 & 0 & \\
\hline \multicolumn{9}{|c|}{ Примале кортикостероиди } \\
\hline \multicolumn{4}{|l|}{$\mathrm{He}$} & 3 & 6,5 & & & \\
\hline \multicolumn{4}{|l|}{ Да } & 43 & 93,5 & & & \\
\hline \multicolumn{4}{|c|}{ VFA (Vertebral Fracture Assessment) } & & & & & \\
\hline
\end{tabular}




\begin{tabular}{|l|c|c|c|c|c|}
\hline Нема & 17 & 37,0 & 14 & 3 & $0,040160^{*}$ \\
\hline Лесна & 9 & 19,5 & 9 & 0 & \\
\hline Средна & 17 & 37,0 & 17 & 0 & \\
\hline Тешка & 3 & 6,5 & 3 & 0 & \\
\hline ВMD (Bone Mineral Density) & & & & & \\
\hline Нормална & 14 & 30,4 & 11 & 3 & $0,025533^{*}$ \\
\hline Остеопенија & 29 & 63,0 & 29 & 0 & \\
\hline Остеопороза & 3 & 6,6 & 3 & 0 & \\
\hline
\end{tabular}

*Fisher Exact 2 tailed test

Табела 1. Демографски и клинички карактеристики

\section{Дискусија}

Остеопорозата кај RA се јавува како дел од клиничката слика, но и како несакан ефект поради хоничната терапија со мали дози гликокортикоиди. Студијата на Laan RF и сор. покажала дека 9,5\% од коскената густина на прешленските трабекуларни коски се губи во период од само неколкунеделна терапија при дневна доза од 7,5 мг преднизолонски еквивалент ${ }^{6}$.

Во нашиот случај, регистриравме остеопороза кај 6,6\% од пациентките, а остеопенија кај дури 63,6\%. Постоеше сигнификантна поврзаност помеѓу BMD и земањето GC, за $\mathrm{p}<0,05$ (0,025533). Во нашата студија, вредностите за вкупниот T-score на лумбалниот "рбет како и T-score на левиот колк значајно се разликуваа во двете групи пациентки, односно помеѓу пациентките со и пациентките без GC терапија. Пациентките кои беа на GC- терапија беа со зголемен ризик од настанување на фрактура. Студијата покажа дека 37,0\% од постменопаузните пациентки со RA кои беа на GC терапија појавија вертебрални фрактури. Во споредба со студијата на El Maqhraoui и cop. ${ }^{10}$ каде што процентот на појава на VF изнесувал 36\%, а просечната старост изнесувала 49,4 години, во нашата студија добивме повисока застапеност на VF, бидејќи просечната старост на нашите испитанички изнесуваше 62+-7,9 години. Во студијата на Mochamed и cop. застапеноста на VF се јавила во помал процент, но просечната старост кај тие пациентки била значително помала и изнесувала 43,11 години ${ }^{11}$. Оттука, јасна е поврзаноста на возраста на пациентките со застапеноста на VF кај нашите испитаници. Фрактурите на ,рбетот се најчестите остеопоротични фрактури. Тие се важни за навремено откривање бидејќи се поврзани со значителен морбидитет, морталитет и намален квалитет на живот ${ }^{5,12,13}$. Со снимање на тораколумбалниот 'рбет (Т4-Л4) со помош на коскен дензитометар кој има вграден софтвер за VFA, се овозможува детекција на вертебрални фрактури дури и кога нема клинички манифестации ${ }^{14}$. Само една третина од VF може да се детектира и дијагностицира со помош на радиографија. Затоа, снимањето со коскен дензитометар и проценката на VF co VFA е неопходно за нивно рано и навремено откривање15,16. Дури и кога рендгенските фрактури се присутни на радиографиите, тие често не се препознаваат од страна на радиологот и не доведуваат до дијагноза и соодветен третман на остеопорозата ${ }^{17,18}$. 


\section{Заклучок}

Кај постменопаузните пациентки co RA кои беа на терапија со GC беше регистрирана почеста појава на остеопороза и нејзината сериозна компликација -појава на вертебрални фрактури, споредено со постменопаузните пациентки co RA кои не се лекувале со гликокортикоиди. Студијата покажа дека 37,0\% од постменопаузните пациентки со RA кои беа на гликокортикоидна терапија имаа појава на вертебрални фрактури. Исто така, намалувањето на коскената маса и густина на ниво на левиот колк, одредено со коскен дензитометар (преку T- score на вкупниот лев колк) беше статистички значајно поголемо кај пациентките кои земаа гликокортикоиди. Значајно е да се истакне дека нашите испитаници кои беа лекувани co GC, примале мали дози на гликокортикоиди. Нашата студија фрли дополнително светло врз негативните ефекти од малите дози на гликокортикоиди. Според добиените резултати, може да се заклучи дека малите дози на GC неосновано се сметаат за безбедни и сигурни.

Кај сите пациентки со RA, особено оние кои се на хронична терапија co GC, потребно е да се спроведува евалуација на остеопорозата и одредување на коскената густина на прешленските тела со помош на VFA во одредени временски интервали за да се овозможи рано, навремено детектирање, лекување на остеопорозата и превенирање на вертебрални и невертебрални фрактури.

\section{Референци}

1. Coulson KA, Reed G, Gilliam BE, Kremer JM, Pepmueller PH. Factors influencing fracture risk, T score, and management of osteoporosis in patients with rheumatoid arthritis in the Consortium of Rheumatology Researchers of North America (CORRONA) registry. J Clin Rheumatol 2009;15:155-60.

2. Gabriel SE, Michaud K. Epidemiological studies in incidence, prevalence, mortality and comorbidity of the rheumatic diseases. Arthritis Res Ther 2009;11:229.

3. Van Staa TP, Leufkens HG, Cooper $\mathrm{C}$. The epidemiology of corticosteroid-induced osteoporosis: a metaanalysis. Osteoporos Int 2002;13:777-87.

4. Pereira IA, Mota LM, Cruz BA, et al. Consensus on the management of comorbidities in patients with rheumatoid arthritis. Rev Bras Reumatol 2012;52:474-95.

5. Lindsay R, Silverman SL, Cooper S, et al. Risk of new vertebral fracture in the year following a fracture. JAMA 2001; 285:320-3.

6. Laan RF, van Riel PL, van de Putte LB, van Erning LJ, van Hof MA, Lemmens JA. Low-dose prednisone induces rapid reversible axial bone loss in patients with rhumatoid arthritis: A randomized, controlled study. Ann Intern Med 1993;119:9638.

7. Arnett FC, Edworthy SM, Bloch DA, McShane DJ, Fries JF, Cooper NS, Healey LA, Kaplan SR, Liang $\mathrm{MH}$, Luthra HS, et al.The American Rheumatism Association 1987 revised criteria for the classification of rheumatoid arthritis. Arthritis Rheum 1988;31:315-24.

8. Center JR, Nguyen TV, Schneider D, Saambrock PN, Eisman JA. Mortality after all major types of osteoporotic fracture in men and women: an observational study. Lancet 1999;353:878-82. 
9. Lewiecki EM, Laster AJ. Clinical review: Clinical applications of vertebral fracture assessment by dual-energy x-ray absorptiometry. J Clin Endocrinol Metab 2006;91:4215-22.

10. El Maghraoui A, Rezqi A, Mounach $\mathrm{A}$, et al. Prevalence and risk factors of vertebral fractures in women with rheumatoid arthritis using vertebral fracture assessment. Rheumatology 2010; 49:1303-1310.

11. El-Wakd M, Omar H.O, Abousenna H. Prevalence of silent nontraumatic vertebral fracture in rheumatoid arthritis: relation with disease duration, disease activity, corticosteroid, and hip buckling ratio. Egyptian Rheumatology and Rehabilitation 2014;41:116-121.

12. Melton LJ 3rd, Atkinson EJ, Cooper C, O'Fallon WM, Riggs. Vertebral fractures predict subsequent fractures. Osteoporosis Int 1999; 10:214221

13. Delmas PD, van de Langerijt $\mathrm{L}$, Watts NB, Eastell R, Genant H,Grauer A, Cahall DL. Underdiagnosis of vertebral fractures is a worldwide problem: the IMPACT Study. J Bone Miner Res 2005; 20:557-563.
14. Center JR, Bliuc D, Nguyen TV, Eisman JA. Risk of subsequent fracture after low-trauma fracture in men and women. JAMA 2007; 297:387394

15. Cauley JA, Hochberg MC, Lui LY, Palermo L, Ensrud KE, HillierTA, Nevitt MC, Cummings SR. Long-term risk of incident vertebral fractures. JAMA 2007; 298:2761-2767

16. Cooper C, O'Neill T, Silman A. The epidemiology of vertebral fractures. European Vertebral Osteoporosis Study Group. Bone 1993; 14:S89-97

17. Fink HA, Milavetz DL, Palermo L, Nevitt MC, Cauley JA, et al. What proportion of incident radiographic vertebral deformities is clinically diagnosed and vice versa. J Bone Miner Res 2005;20:1216-1222

18. Haugeberg G, Uhlig T, Falch JA, Halse JI, Kvien TK. Bone mineral density and frequency of osteoporosis in female patients with rheumatoid arthritis: results from 394 patients in the Oslo County rheumatoid arthritis register. Arthritis Rheum 2000;43:522-30. 